\title{
Immediate and long term results of percutaneous coronary angioplasty in patients aged 70 and over
}

Peter de Jaegere, Pim de Feyter, Ron van Domburg, Haryanto Suryapranata, Marcel van den Brand, Patrick W Serruys

\begin{abstract}
Objective-To study the immediate and long term clinical success of percutaneous transluminal coronary balloon angioplasty in patients over 70 years old.

Design-Patients undergoing percutaneous transluminal angioplasty were prospectively entered in a specially designed database. The clinical and angiographic data of all patients over 70 were reviewed. Follow up data were collected by interview during outpatient visits, by questionnaire, or through the referring
\end{abstract} physician.

Setting-A tertiary referral cardiac centre.

Patients-166 patients over 70 (median 73, range 70-84) underwent coronary angioplasty because of unstable angina (81 patients), stable angina (76 patients), or acute myocardial infarction (nine patients).

Results-The initial clinical success rate was $86 \%$ (142 of 166 patients). A major procedural complication occurred in 10 patients $(6 \%)$ : four patients $(2 \%)$ died, six patients $(4 \%)$ underwent emergency bypass surgery, and five patients (3\%) sustained an acute myocardial infarction. In 14 patients $(8 \%)$ coronary angioplasty did not significantly reduce the diameter stenosis but there were no associated complications. A total of 226 lesions were attempted. The initial angiographic success rate was 192 out of 226 lesions (85\%). The median follow up was 21 (range 0.5-66) months. Sixteen patients $(10 \%)$ died during follow up, eight patients ( $5 \%$ ) sustained a non-fatal myocardial infarction, 21 patients (13\%) underwent a second or third balloon dilatation, and 17 patients $(10 \%)$ underwent elective bypass surgery. Of the 146 survivors, 99 patients $(68 \%)$ had sustained clinical improvement. The estimated survival at four years (KaplanMeier method) was 89 (SD 4)\%. The event free survival at four years for the total study population was 61 (8)\%. Multivariate logistic regression analysis showed that the extent of vessel disease was the only independent predictive factor for event free survival: the event free survival rate was $81(10) \%$ at four years for patients with single vessel disease, compared with $45(12) \%$ for patients with multivessel disease.

Conclusions-Coronary angioplasty in patients over 70 was a safe and effective treatment for obstructive coronary artery disease. The extent of vessel disease, and not the completeness of revascularisation, was the only independent predictive factor for event free survival.

An increasing proportion of the population consists of elderly people. ${ }^{1}$ Because the incidence of coronary heart disease increases with age, it is not surprising that more and more elderly patients are referred for coronary angiography. ${ }^{2}$ As a consequence, the numbers of coronary angioplasty procedures and coronary artery bypass operations in this subgroup of the population will increase as well. Coronary artery bypass grafting in geriatric patients is associated with increased morbidity and mortality. ${ }^{3-5}$ Coronary angioplasty is a less invasive procedure and may be an attractive non-surgical alternative. In general, the elderly patient has more advanced coronary artery disease and lesions that are more calcified. Sometimes the coronary arteries are rigid and tortuous. ${ }^{5-7}$ These morphological and angiographic characteristics make coronary angioplasty technically more difficult to perform and may lead to less satisfactory results.

We examined the safety and efficacy of coronary angioplasty in elderly patients in terms of the initial angiographic and clinical success rate and the long term results.

\section{Patients and methods}

Between January 1983 and September 1988 coronary angioplasty was performed in 166 patients over 70 years old. They represent $8 \%$ of the total coronary angioplasty population $(n=2002)$ during the same period. Table 1 shows the clinical and angiographic character-

Table 1 Clinical and angiographic characteristics

\begin{tabular}{ll}
\hline Characteristic & Patients $\boldsymbol{n}(\%)$ \\
\hline Total number of patients & 166 \\
Age (yr): & 73 \\
Median & $(70-84)$ \\
Range & $86(52)$ \\
Male & $65(39)$ \\
Previous myocardial infarction & $17(10)$ \\
Previous coronary artery bypass surgery & $87(52)$ \\
Vessel disease: & $52(31)$ \\
Single & $27(16)$ \\
Double & \\
Triple & 59 \\
Ejection fraction (\%): & $(18-77)$ \\
$\quad$ Median & \\
Range & \\
\hline
\end{tabular}


istics. The indication for coronary angioplasty was unstable angina in 81 patients $(49 \%)$, stable angina in 76 patients $(46 \%)$, and acute myocardial infarction in nine patients $(5 \%)$. Until 1988, patients with an acute myocardial infarction were treated with intravenous and intracoronary streptokinase followed by angioplasty if the residual stenosis was $.50 \%$. Unstable angina pectoris was defined as angina at rest associated with reversible changes in the ST segment or $\mathrm{T}$ wave without evidence of ensuing myocardial necrosis as assessed by increased cardiac enzyme activity or the development of new $Q$ waves. Seven patients underwent coronary angioplasty of a stenosis in the left main stem. Two patients had a left main stem artery protected by the presence of a patent bypass graft, one patient was admitted because of an acute myocardial infarction complicated by cardiogenic shock, and four patients were regarded as high risk surgical cases because of severe peripheral vascular disease, renal insufficiency, obstructive lung disease, or previous stroke.

The global ejection fraction was calculated from a single plane left ventricular angiogram in the $30^{\circ}$ right anterior oblique view according to Simpson's rule.

\section{CORONARY ARTERIOGRAPHY}

Coronary arteriography was performed via the femoral approach, with multiple views that included hemiaxial projections. The degree of stenosis was expressed as the percentage reduction in the diameter of the coronary artery lumen. A reduction in diameter of $>$ $50 \%$ was regarded as significant. The culprit lesion in patients with acute myocardial infarction or unstable angina and multivessel disease was identified by relating the site of changes in the resting ST segment and $T$ wave on the standard 12 lead electrocardiogram to the angiographic findings. ST-T segment changes in leads $\mathrm{I}, \mathrm{aVL}$, and V1-6 were related to lesion(s) of the left anterior descending coronary artery. Changes in leads II, III, and aVF were related to lesion(s) of the right or circumflex coronary artery. A total occlusion was defined as the absence of anterograde flow, and a functionally occluded artery was defined as the incomplete opacification of the distal vessel.

\section{CORONARY ANGIOPLASTY}

Coronary angioplasty was performed with preformed guiding catheters, steerable dilating balloon catheters, and a pneumatic inflation device. Before the dilatation, a 7 French pacing electrode was positioned in the right atrium, and 10000 units of heparin and $250 \mathrm{mg}$ of aspirin were administered intravenously. Intracoronary isosorbide dinitrate was given to prevent coronary spasm. Four electrocardiographic leads and the aortic pressure were monitored continuously. Balloon inflation started at a pressure of $2 \mathrm{~atm}$ and was increased to $12 \mathrm{~atm}$ if necessary. The inflation was stopped when electrocardiographic changes, a considerable drop in blood pressure, or pain developed. The dilatation was repeated until there was a significant reduction of the diameter stenosis. Angioplasty was considered to be angiographically successful when obstruction of the luminal diameter was reduced to $<50 \%$. A dissection was defined as the presence of intimal damage producing an intraluminal defect on the coronary angiogram, or extraluminal extravasation of contrast material, or the presence of linear luminal density or luminal staining, or a combination of these.

A clinically successful angioplasty was defined as an angiographically successful dilatation free of procedure related complications that led to acute myocardial infarction, emergency bypass surgery, or death. A periprocedural infarction was determined by the development of new $Q$ waves $(0.04 \mathrm{~s})$ or an increase in serum cardiac enzyme activities of more than twice the upper limit of normal. A perioperative myocardial infarction was defined by the development of new $Q$ waves.

Dilatation within two or more major coronary arteries was described as multivessel angioplasty. Revascularisation was considered complete when all stenoses leading to a diameter reduction of $>50 \%$ were successfully dilated.

\section{FOLLOW UP}

Procedural details, including immediate complications, were prospectively recorded in a computer database at the time of balloon angioplasty. The median follow up time was 21 (range 0.5-66) months. Patients were screened for the occurrence of death, acute myocardial infarction, and recurrent angina necessitating repeat angioplasty or bypass surgery. Clinical follow up information was obtained at interview during outpatient visits, by questionnaire, or through the referring physician. Information was complete for all patients. Patient survival curves and event free plots were constructed by the KaplanMeier method.

\section{Results}

\section{ANGIOGRAPHIC RESULTS}

Percutaneous transluminal coronary angioplasty was performed in 166 patients over 70 years old. Angioplasty was attempted on a total of 226 lesions (one lesion in 117 patients $(70 \%)$, two or more lesions in 49 patients $(30 \%)$ ). Revascularisation was complete in 101 patients $(61 \%)$ and partial in 65 patients $(39 \%)$.

Of the 226 stenoses, 192 were successfully

Table 2 Distribution, aspect, and angiographic success of lesions on which angioplasty was. attempted

\begin{tabular}{lrr}
\hline & No (\%) & $\begin{array}{l}\text { Success } \\
\text { rate (\%) }\end{array}$ \\
\hline Total number of lesions & 226 & $192(85)$ \\
Site: & $128(57)$ & $114(89)$ \\
LAD & $49(22)$ & $40(82)$ \\
CX & $38(17)$ & $18(74)$ \\
RCA & $7(3)$ & $6(86)$ \\
Left main stem & $4(2)$ & $4(100)$ \\
Venous graft & $11(5)$ & $9(82)$ \\
Functionally occluded artery & $15(7)$ & $9(60)$ \\
Totally occluded artery & & \\
\hline
\end{tabular}

LAD, left anterior descending coronary artery; $\mathrm{CX}$, circumflex coronary artery; RCA, right coronary artery. 
Table 3 Clinical success of coronary angioplasty and procedure related major complications in 166 patients over 70

\begin{tabular}{lr}
\hline Patients over 70 & No $(\%)$ \\
\hline Total number of patients & 166 \\
Clinical success & $142(86)$ \\
Unsuccessful angioplasty without complications & $14(8)$ \\
Unsuccessful angioplasty with complications: & $10(6)$ \\
Death & $4(2)$ \\
AMI & $5(3)$ \\
CABG & $6(4)$ \\
\hline
\end{tabular}

AMI, acute myocardial infarction; CABG, coronary artery bypass grafting.

Table 4 Clinical success of coronary angioplasty according to indication in 166 patients aged $\geqslant 70$

\begin{tabular}{llc}
\hline & $\begin{array}{l}\text { No of patients } \\
\text { in which angioplasty } \\
\text { was attempted }\end{array}$ & Success (\%) \\
Indication & 81 & $73(90)$ \\
UAP & 76 & $61(80)$ \\
AP & 9 & $8(81)$ \\
\hline
\end{tabular}

UAP, unstable angina pectoris; AP, stable angina pectoris; AMI, acute myocardial infarction.

dilated. The overall primary angiographic success rate was $85 \%$. Table 2 shows the distribution of the lesions and the success rate per lesion. The lesion could not be crossed in four patients $(2 \%)$. In three of these the attempt to cross the lesion with the guide wire resulted in dissection and subsequent occlusion. These three patients died of acute myocardial infarction complicated by cardiogenic shock. The fourth patient was referred for emergency bypass surgery. Abrupt closure of the artery immediately after attempted dilatation occurred in 10 patients $(6 \%)$. In three patients a major coronary dissection was found, but in the other seven patients the mechanism of the acute occlusion was uncertain. They were all successfully redilated. A dissection was seen in another 14 patients $(8 \%)$. One patient died, one sustained an acute myocardial infarction, and three underwent emergency bypass surgery.

CLINICAL RESULTS

The primary clinical success rate for the total study population was $86 \%$ (table 3 ). In 14 patients $(8 \%)$ the angioplasty did not significantly reduced the diameter stenosis, but there were no complications. Ten patients $(6 \%)$ had a major procedure related complication. Acute myocardial infarction was seen in four patients, of whom one died and two were referred for emergency bypass surgery. Another four patients underwent urgent bypass surgery, of these one patient died of a

Table 6 Major cardiac events during follow up of 166 patients aged $\geqslant 70$ who underwent coronary angioplasty

\begin{tabular}{llllll}
\hline Event & $\begin{array}{l}\text { Group 1 } \\
(\%)\end{array}$ & $\begin{array}{l}\text { Group 2 } \\
(\%)\end{array}$ & $\begin{array}{l}\text { Group 3 } \\
(\%)\end{array}$ & $\begin{array}{l}\text { Total } \\
(\%)\end{array}$ & $\begin{array}{l}\text { Interval (months) } \\
\text { Median (range) }\end{array}$ \\
\hline Death & $142(86)$ & $14(8)$ & $10(6)$ & 166 & $16(10)$ \\
AMI & 13 & 3 & -1 & $8(5)$ & $9(0 \cdot 5-39)$ \\
Re PTCA & 21 & 4 & $-12-13)$ \\
CABG & 12 & 2 & 3 & $21(13)$ & $5(1-32)$ \\
\hline
\end{tabular}

Group 1, successful coronary angioplasty; group 2, unsuccessful coronary angioplasty without complications; group 3, unsuccessful coronary angioplasty with major complications; AMI acute myocardial infarction; Re PTCA, repeat coronary angioplasty; CABG, coronary artery bypass grafting.
Table 5 Complication rate of single vessel and multivessel angioplasty in patients aged $\geqslant 70$

\begin{tabular}{lcc}
\hline & $\begin{array}{l}\text { Single vessel } \\
(\%)\end{array}$ & $\begin{array}{l}\text { Multivessel } \\
(\%)\end{array}$ \\
\hline Total number of patients & 146 & 20 \\
Death & $3(2 \cdot 1)$ & $1(5)$ \\
AMI & $4(2 \cdot 7)$ & $1(5)$ \\
CABG & $5(3 \cdot 4)$ & $1(5)$ \\
\hline AMI, procedure related acute myocardial infarction; CABG, \\
emergency bypass surgery.
\end{tabular}

perioperative myocardial infarction. Two other patients had ventricular fibrillation during angioplasty and subsequently died. A total of 15 complications occurred in 10 patients $(6 \%)$. Table 4 shows the clinical success according to indication. One patient sustained a transient ischaemic cerebrovascular accident and another patient required surgical repair of a pseudoaneurysm of the right femoral artery. Single vessel and multivessel angioplasty were performed in $146(88 \%)$ and 20 patients $(12 \%)$ respectively. Of the 146 patients who underwent single vessel angioplasty, one lesion was attempted in 117 patients $(80 \%)$, and two or more lesions were attempted within the same coronary artery in 29 patients $(20 \%)$. A total of 12 events occurred in eight patients undergoing single vessel angioplasty and three events occurred in two patients undergoing multivessel angioplasty (table 5 ).

\section{FOLLOW UP}

Table 6 lists the data from the clinical follow up after successful and unsuccessful angioplasty. There were 16 deaths (10\%) of which 10 were cardiac and six non-cardiac. Eight patients $(5 \%)$ sustained a late non-fatal acute myocardial infarction. Symptoms recurred in 44 patients $(27 \%)$. Six patients $(4 \%)$ were treated medically. Repeat angioplasty was carried out on 21 patients $(13 \%)$ (the same lesion in 13 patients and a newly acquired lesion in eight patients), of whom one died and four underwent a third uncomplicated coronary angioplasty. Seventeen patients $(10 \%)$ underwent elective bypass surgery; one of these patients had an uncomplicated perioperative myocardial infarction. Table 6 shows the interval between the first coronary angioplasty and the cardiac events during follow up.

The mean (SD) estimated survival at four years from the first angioplasty for the entire study population was 89 (4)\% (fig 1). The event free survival at four years (free of myocardial infarction, bypass surgery, and repeat angioplasty) was 61 (8)\% (fig 1). To determine independent predictors for event free survival, multivariate logistic stepwise regression analysis was performed. Several variables were selected-namely, age $>75$ years, sex, previous myocardial infarction, previous bypass surgery, ejection fraction $<55 \%$, stable $v$ unstable angina, completeness of revascularisation, and extent of vessel disease (single $v$ multivessel disease). The extent of vessel disease was the only independent predictive factor. The probability of sustaining a cardiac event was 4.7 fold higher ( $95 \%$ confidence interval $2 \cdot 3-9 \cdot 3$ ) in patients with multivessel 


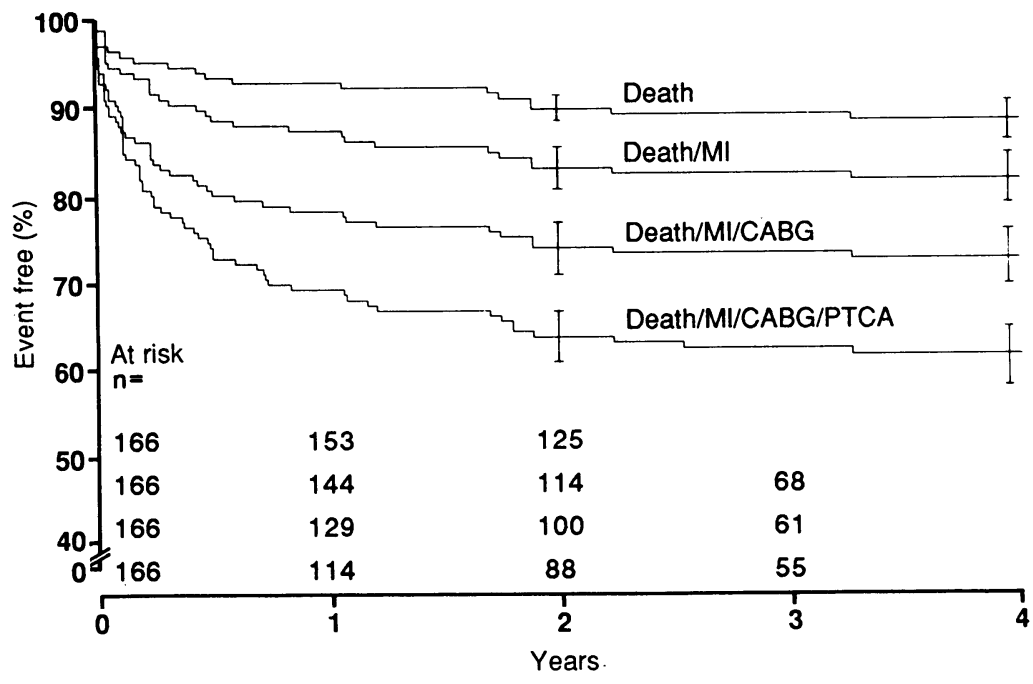

Figure 1 Overall long term cumulative survival and event free survival curves after balloon angioplasty according to the Kaplan-Meier method for patients aged $\geqslant 70$. Vertical bars denote the $95 \%$ confidence intervals. For abbreviations see table 6.

disease compared with those with single vessel disease. Event free survival at four years was $\mathbf{8 1}$ (10)\% in patients with single vessel disease compared with $45(12) \%$ in patients with multivessel disease (fig 2).

At the end of follow up 146 patients (88\%) were still alive. Ninety nine patients $(68 \%)$ were improved clinically. This was associated with an appreciable reduction in antianginal therapy. Before angioplasty, 136 patients were being treated with $\beta$ blockers, 107 with nitrates, and 145 patients with calcium antagonists. At the end of follow up only 41 patients still took $\beta$ blockers (a reduction of $70 \%$ ), 18 still took nitrates (a reduction of $83 \%$ ), and 106 patients took calcium antagonists (a reduction of $27 \%$ ).

\section{Discussion}

As the population of developed countries ages the number of elderly patients referred for diagnostic and therapeutic cardiac catheterisations continues to increase. From January 1983

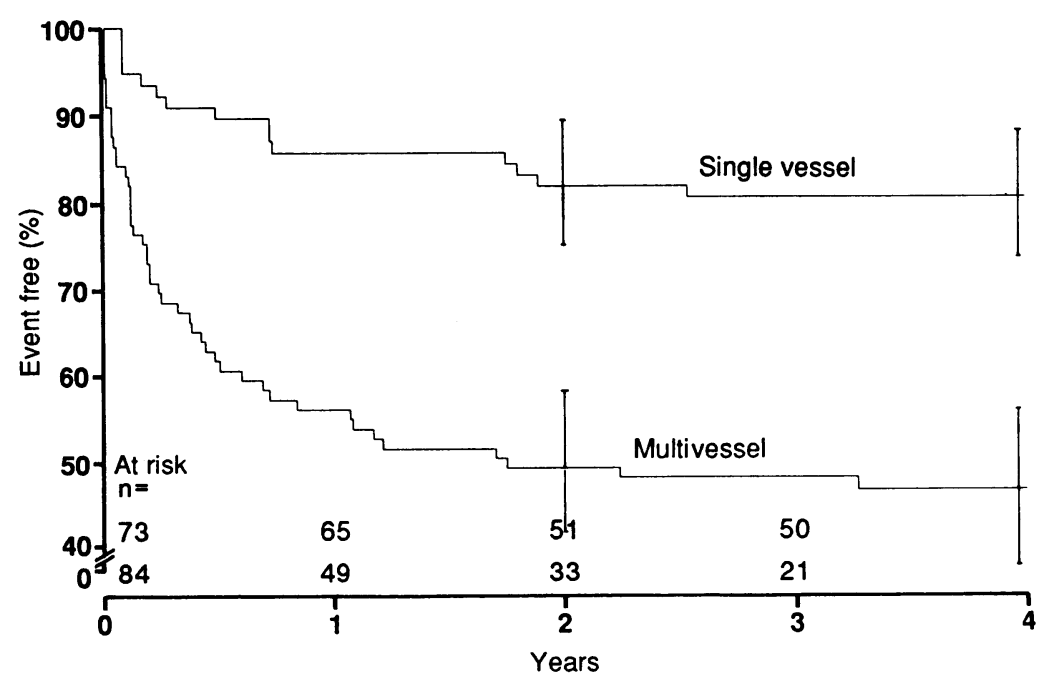

Figure 2 Event free survival after balloon angioplasty according to the Kaplan-Meier method for patients aged $\geqslant 70$ with single or multivessel disease. Vertical bars are $95 \%$ confidence intervals. to August 1988, 2002 coronary angioplasties were performed in our hospital and the percentage of patients over 70 who underwent balloon angioplasty increased from $7 \%$ to $15 \%$. In the United States one third of the cardiac catheterisations and one third of the coronary artery bypass operations are performed on elderly patients. ${ }^{89}$ Coronary artery bypass grafting in the elderly is an effective method of myocardial revascularisation, providing symptomatic relief and good long term results..$^{10-12}$ Cardiac surgery in the geriatric patient is, however, associated with increased morbidity and mortality. ${ }^{31213}$ In view of this high operative risk, coronary angioplasty is particularly attractive as a less invasive alternative. It offers the potential for myocardial revascularisation with certain advantages over bypass grafting such as the avoidance of a thoracotomy, shorter time in hospital, and lower costs. ${ }^{6714}$ A lower success rate may be expected for balloon angioplasty performed in the elederly. As well as the increased procedural mortality known to occur in patients over 70 , other clinical variables noted more often in the elderly, such as depressed left ventricular function and left main and three vessel coronary artery disease, increase the risk associated with balloon angioplasty. ${ }^{1516}$ Elderly patients also have more tortuous coronary arteries and more calcified lesions, which create troublesome angles and bends to negotiate..$^{5-7}$ Our data from this study indicate that coronary angioplasty can be performed with a high initial success rate and an acceptable incidence of complications in patients over 70 . These data accord with previous reports (table 7). Three earlier studies compared the primary success rate and incidence of complications of balloon angioplasty between patients younger than and older than $65 .^{1417}$ Only the National Heart, Lung and Blood Institute (NHLBI) percutaneous transluminal coronary angioplasty registry showed a significantly lower initial success rate and a higher mortality in the elderly patients. ${ }^{14}$ The population of the NHLBI study, however, differed from the other studies in that the data were collected from many institutions during the period 1977 to 1981 . The higher success rate reported in the other studies can in part be explained by improved angioplasty equipment and increased operator experience. Also in this study and in other reports no patients sustained an irreversible cerebrovascular accident whereas $2 \cdot 7-7 \cdot 5 \%$ of patients in surgical series did. ${ }^{61121}$

Though it is difficult to compare different studies, especially when there is selection bias, there is a striking similarity between the overall and the event free survival rates in our patient group and those reported by others. ${ }^{19-21}$ Also, the estimated survival at four years of $89(4) \%$ compares favourably with the survival rate for elderly patients who undergo bypass surgery. ${ }^{112425}$ The importance of complete revascularisation after bypass surgery is well documented. ${ }^{26} 27$ It has been shown that complete revascularisation is associated with improved long term survival and freedom from late cardiac events. ${ }^{28-30}$ Variables other than the 
Table 7 Reported angiographic and clinical success rate and complications after balloon angioplasty in elderly patients

\begin{tabular}{|c|c|c|c|c|c|c|c|}
\hline \multirow[b]{2}{*}{ Author } & \multirow{2}{*}{\multicolumn{2}{|c|}{ Number of patients }} & \multirow[b]{2}{*}{ Angiographic success (\%) } & \multirow[b]{2}{*}{ Clinical success (\%) } & \multicolumn{3}{|c|}{ Complications (\%) } \\
\hline & & & & & Death & $A M I$ & $C A B G$ \\
\hline \multicolumn{8}{|c|}{ Patients $\geqslant 65$ years } \\
\hline $\begin{array}{l}\text { Mock et al }{ }^{14} \\
\text { Jones et al }{ }^{17} \\
\text { Raizner et al }{ }^{18} \\
\text { Bedotto et al }\end{array}$ & $\begin{array}{l}1984 \\
1986 \\
1986 \\
1991\end{array}$ & $\begin{array}{r}370 \\
159 \\
119 \\
1373\end{array}$ & $\begin{array}{l}\overline{84} \\
81 \\
96\end{array}$ & $\begin{array}{l}53 \\
81 \\
-\end{array}$ & $\begin{array}{l}2 \cdot 2 \\
0.0 \\
0.8 \\
1.6\end{array}$ & $\begin{array}{l}5 \cdot 6 \\
3 \cdot 1 \\
2 \cdot 5 \\
1 \cdot 4\end{array}$ & $\begin{array}{l}6 \cdot 8 \\
5 \cdot 7 \\
4 \cdot 1 \\
0 \cdot 8\end{array}$ \\
\hline $\begin{array}{l}\text { Dorros and Janke } \\
\text { Holt } e t a^{20} \\
\text { Simpfendorfer et } a l^{21}\end{array}$ & $\begin{array}{l}1986 \\
1988 \\
1988\end{array}$ & $\begin{array}{l}109 \\
54^{\star} \\
124 \dagger \\
212^{\star}\end{array}$ & $\begin{array}{l}\text { Patients } \geqslant 70 \text { years } \\
= \\
=\end{array}$ & $\begin{array}{l}83 \\
80 \\
90 \\
93\end{array}$ & $\begin{array}{l}1.8 \\
0.0 \\
0.0 \\
0.9\end{array}$ & $\begin{array}{l}2 \cdot 8 \\
4 \cdot 0 \\
0.8 \\
0.9\end{array}$ & $\begin{array}{l}0.9 \\
6 \cdot 0 \\
4 \cdot 0 \\
2 \cdot 8\end{array}$ \\
\hline $\begin{array}{l}\text { Kern et al } \\
\text { Rich et } \text { al }^{23}\end{array}$ & $\begin{array}{l}1988 \\
1990\end{array}$ & $\begin{array}{l}21 \\
22\end{array}$ & $\begin{array}{l}\text { Patients } \geqslant 80 \text { years } \\
78 \\
89\end{array}$ & $\frac{67}{-}$ & $\begin{array}{r}19 \cdot 0 \\
0.0\end{array}$ & $\overline{14} \cdot 0$ & $\begin{array}{l}1.4 \\
0.0\end{array}$ \\
\hline
\end{tabular}

AMI, acute myocardial infarction; CABG, emergency bypass surgery. ${ }^{\star}$ Only patients with unstable angina; fonly patients with stable angina.

degree of revascularisation, however, may influence the long term outcome. Moreover, there may be substantial differences in baseline characteristics between patients with complete and incomplete revascularisation. ${ }^{31} 32$ In this respect, conclusions about long term outcome based only on the degree of revascularisation may be misleading. It has been shown that after adjustment of such baseline differences in patients with multivessel disease undergoing balloon angioplasty, the completeness of revascularisation has no independent predictive value for event free survival. ${ }^{31}{ }^{32}$ The data from this study indicate that the extent of vessel disease and not the degree of revascularisation is the only independent predictor for event free suurvival.

\section{STUDY LIMITATIONS}

The group of patients we describe is clearly a selected population. Patients were not randomised to either angioplasty or bypass surgery. Therefore, no attempt was made to compare the results of balloon angioplasty with those achieved by bypass surgery. Published data on angioplasty and coronary artery bypass surgery, however, provide some insight into the benefit:risk ratio when choosing which treatment should be used for the geriatric patients. Angioplasty can only truly be compared with bypass surgery in randomised trials, such as are currently under way in Europe and The United States.

In conclusion, coronary angioplasty can be performed safely and effectively in the elderly. Given the favourable long term results this procedure should be considered as a therapeutic alternative to coronary bypass surgery in this group of patients.

We thank Dr Donald Mcleod for his comments.

1 Simons LA. Epidemiologic considerations in cardiovascular diseases in the elderly: international comparisons and trends. Am J Cardiol 1989;63:5H-8H.

2 Kennedy RD, Andrews GR, Caird FI. Ischaemic heart disease in the elderly. Br Heart J 1977;39:1121-7.

3 Knapp WS, Douglas JS, Craver JM, King SB III, Bone DK, Bradford JM, et al. Efficacy of coronary artery bypass grafting in elderly patients with coronary artery disease. grafting in elderly patients with

4 Faro RS, Golden MD, Javid H, Serry C, DeLaria GA, Monson D, et al. Coronary revascularisation in septuagenarians. J Thorac Cardiovasc Surg 1983;86:616-20.
5 Kennedy JW, Kaider GC, Fisher LD, Fritz JK, Myers W, Mudd G, et al. Clinical and angiographic predictors of operative mortality from the Collaborative Study in operative mortality from the Collaborative Study in

6 Dorros G, Janke L. Percutaneous transluminal coronary angioploasty in patients over the age of 70 years. Cathet Cardiovasc Diagn 1986;12:223-9.

7 Kelly ME, Taylor GJ, Moses HW, Mikell FL, Dove JT, Batchelder JE, et al. Comparative cost of myocardial revascularisation: percutaneous transluminal angioplasty and coronary artery bypass surgery. $\mathrm{J} \mathrm{Am} \mathrm{Coll} \mathrm{Cardiol}$ 1985;5:16-20.

8 Kashyap M. Cardiovascular disease in the elderly: current considerations. Am J Cardiol 1989;63:3H-4H.

9 Stason WB, Sanders CA, Smith HC. Cardiovascular care of the elderly: economic considerations. J Am Coll Cardiol 1987;10:18A-21A.

10 Elayda MS, Hall RJ, Gray AG, Mathur VS, Cooley DA. Coronary revascularisation in the elderly patient. J Am Coll Cardiol 1984;3:1398-402.

11 Horneffer PJ, Gardner TJ, Manolio TA, Hoff SJ, Rykier MF, Pearson TA, et al. The effect of age on outcome after Pearson TA, et al. The effect of age on outcome after
coronary bypass surgery. Circulation 1987;76(suppl V): V6-12.

12 Acinapura AJ, Rose DM, Cunningham JN, Jacobowitz IJ, Kramer MD, Zisbrod Z. Coronary artery bypass in septuagenarians. Analysis of mortality and morbidity. Circulation 1988;78(suppl 1):179-84.

13 Hochberg MS, Levine FH, Daggett WM, Akins CW, Austen G, Buckley MJ. Isolated coronary artery bypass grafting in patients seventy years of age and older. $J$ Thorac Cardiovasc Surg 1982;84:219-23.

14 Mock MB, Holmes DR, Vlietstra RE, Gersh BJ, Detre KM, Kelsey SF, et al. Percutaneous transluminal coronary angioplasty (PTCA) in the elderly patient: experience in the National Heart, Lung and Blood Institute PTCA Registry. Am J Cardiol 1984;53:89C-91C.

15 Hartler GO, Rutherford BD, McConahay DR, Johnson WL, Giorgi LV “High risk" percutaneous transluminal coronary angioplasty. Am J cardiol 1988;61:33G-7G.

16 O'Keefe JH, Rutherford BD, McConahay DR, Johnson WL, Giorgi LV, Lignon RW, et al. Multivessel coronary angioplasty from 1980 to 1989: procedural results and angioplasty from 1980 to 1989: procedural 16:1097-102.

17 Jones EL, Abi-Monsour P, Gruntzig AR. Coronary artery bypass surgery and percutaneous transluminal coronary angioplasty in the elderly. Cardiology 1986;73:223-34.

18 Raizner AE, Hust RG, Lewis JM, Winters WL, Batty JW, Roberts R. Transluminal coronary angioplasty in the elderly. Am J Cardiol 1986;57:29-32.

19 Bedotto JB, Rutherford BD, McConahay DR, Johnson WL, Giorgi LV, Shimshak TM, et al. Results of multivessel percutaneous transluminal coronary angioplasty in persons aged 65 years and older. Am J Cardiol 1991;67: $1051-5$.

20 Holt GW, Stuct: DD, Breshnahan JF, Vliestra RE, Breshnahan DR, Reeder GS, et al. Results of percutaneous transluminal coronary angioplasty for unstable angina in patients 70 years of age and older. Am J Cardiol 1988;61:994-7.

21 Simpfendorfer C, Raymond R, Schraider J, Badhwar K, Dorosti K, Franco I, et al. Early and long-term results of percutaneous transluminal coronary angioplasty in patients 70 years of age and older with angina pectoris. $A m$ J Cardiol 1988;62:959-61.

22 Kern MJ, Deligonoul U, Galan K, Zetman R, Gabliani G. Bell ST, et al. Percutaneous transluminal coronary angioplasty in octogenarians. Am J Cardiol 1.988;61:457-8..

23 Rich JJ, Crispino CM, Saporito JJ, Domat I, Cooper WM. Percutaneous transluminal coronary angioplasty in patients 80 years of age and older. Am J Cardiol 1990; patients 80 : $675-6$.

24 Gersh BJ, Kronmal RA, Schaff HV, Frye RL, Ryan TJ, Mock MB, et al. Comparison of coronary artery bypass Mock MB, et al. Comparison of coronary artery bypass surgery and medical therapy in patients
older. N Engl J Med 1985;313:217-24. 
25 Horvath KA, DiSesa VJ, Peigh PS, Couper GS, Collins JJ, Cohn LH. Favourable results of coronary artery bypass grafting in patients older than 75 years. $J$ Thorac Cardiovasc Surg 1990;99:92-6.

26 Jones EL, Craver JM, Guyton RA, Bone DK, Hatcher CR, Riechwald N. Importance of complete revascularisation in performance of coronary bypass operation. Am J Cardiol 1983;51:7-12.

27 Lawrie GM, Morris GC, Silvers A, Wagner WF, Baron AE, Beltangady SS, et al. The influence of residual disease after Beltangady SS, et al. The influence of residual disease after coronary artery bypass on the 5-year survival rate of 1274
men with coronary artery disease. Circulation 1982; men with

28 Lavee J, Rath S, Tran-Quang-Hoe. Does complete revascularisation by the conventional method truly provide the best possible results? Analysis of results and comparison with revascularisation of infarct-prone segments (systematic segmental myocardial revascularisation): the
Sheba Study. J Thorac Cardiovasc Surg 1986;92:279-90. 29 Cukingnan RA, Carey JS, Witting JH, Brown BG. Influence of complete coronary revascularisation on relief on angina. J Thorac Cardiovasc Surg 1980;79:188-93.

30 Jones EL, Craver JM, Guyton RA, Bone DK, Hatcher CR, Riechwald N. Importance of complete revascularisation in performance of the coronary bypass operation. $A m J$ Cardiol 1983;51:7-12.

31 Reeder GS, Holmes DR, Detre K, Costigan T, Kelsey SF. Degree of revascularisation in patients with multivessel coronary disease: a report from the National Heart, Lung, and Blood Institute Percutaneous Transluminal Coronary and Blood Institute Percutaneous Transluminal Coro

32 Bell MR, Bailey KR, Reeder GS, Lapeyre AC III, Holmes DR. Percutaneous transluminal angioplasty in patients with multivessel coronary disease: how important is with multivessel coronary disease: how important is J Am Coll Cardiol 1990;16:553-62.

\section{PLANTS IN CARDIOLOGY}

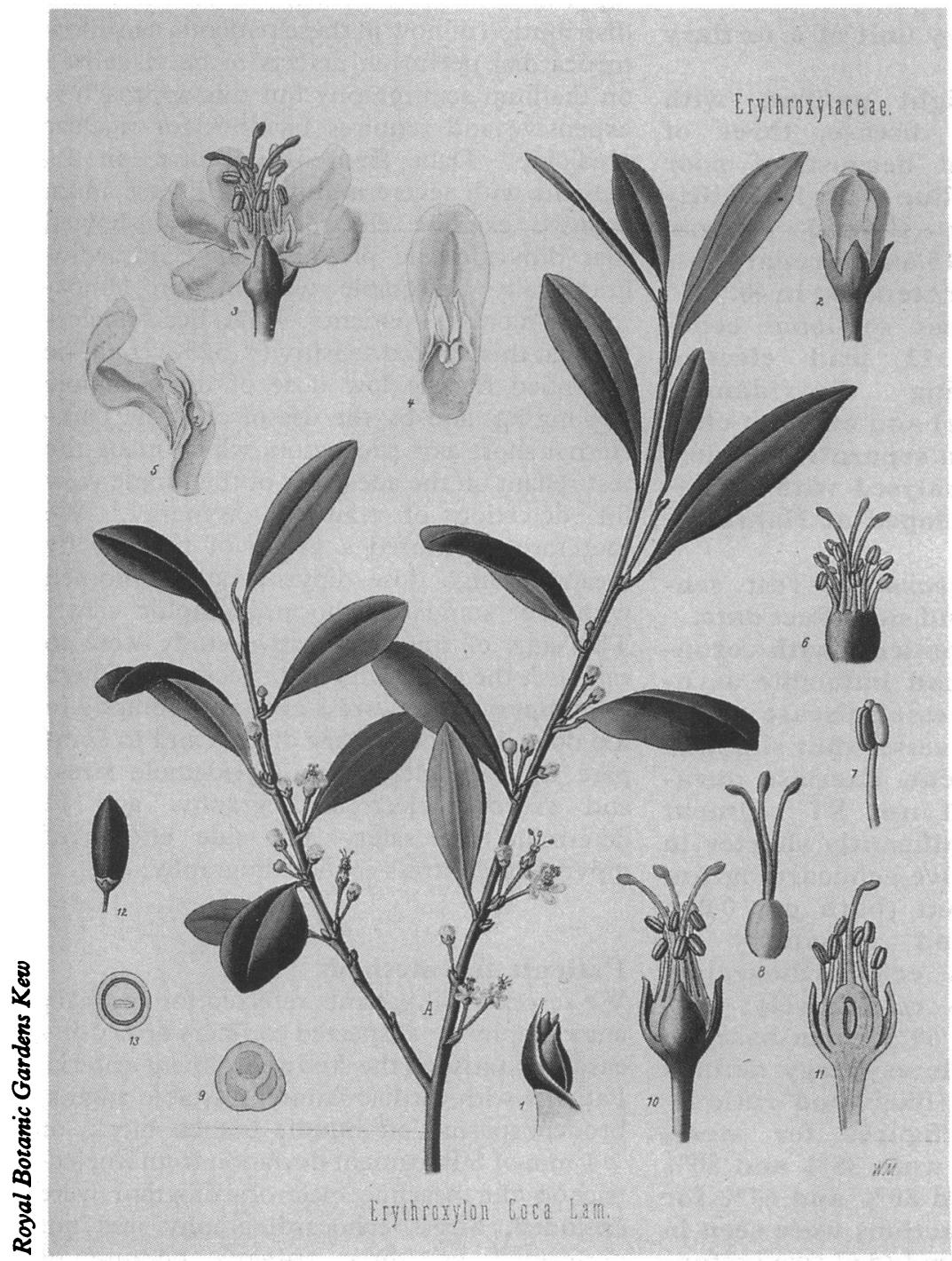

Erythroxylum coca Lam. Kohler F E. MedizinalPflanzen, Atlas. Gera untermhaus: E Kohler, Procaine and procainamide 1887 , plate 76 .
In the early 1930s a Dr Claude S Beck was undertaking pioneer cardiac surgery at the Lakeside Hospital in Cleveland, Ohio. He was attempting to revascularise the heart in angina pectoris by putting a pedicle graft of pectoralis muscle onto the left ventricle and he was also doing pericardiectomy for constrictive pericarditis.

But arrhythmias during and after surgery presented an important problem which was investigated experimentally by Dr Frederick $R$ Mautz. For this study he chose drugs in the cocaine group because they were readily absorbed from mucous membranes and were already known to have some effect on the myocardium. Mautz showed that in dogs procaine produced a monophasic local injury current in the epicardial electrogram and that it prevented extrasystoles when the heart was stimulated electrically (Journal of Thoracic Surgery 1936;5:612-28). Procaine had a quinidine-like effect but its action was short-lived owing to esterase action. Its analogue procainamide (Pronestyl) introduced in 1951 had the advantages of being enzyme resistant and active by mouth.

Cocaine was isolated in 1860 from the South American coca plant Erythroxylum coca (Erythroxylaceae). This shrub, the "divine plant of the Incas", grows in the eastern Andes and had been used since ancient times to induce a pleasant mental state, to combat fatigue, and increase physical endurance. This folk medicine interested Sigmund Freud and in 1884 he studied the properties of cocaine with the help of his Viennese colleague Carl Koller who was an eye surgeon. When it was found that cocaine numbed the tongue Koller at once realised its potential in ophthalmic surgery. It soon became widely used as the first ever local anaesthetic but its stimulant effect on the nervous system was unwelcome-though Sherlock Holmes took advantage of it. The less toxic synthetic compound procaine was made in 1905.

The small tropical family Erythroxylaceae has no other species with medical uses. It is interesting that two other antiarrhythmic compounds namely lignocaine and quinine are also local anaesthetics (British Heart Journal 1991; 65:165 and 66:301). 